\title{
ARHGEF12 wt Allele
}

National Cancer Institute

\section{Source}

National Cancer Institute. ARHGEF12 wt Allele. NCI Thesaurus. Code C97437.

Human ARHGEF12 wild-type allele is located in the vicinity of 11q23.3 and is approximately $153 \mathrm{~kb}$ in length. This allele, which encodes Rho guanine nucleotide exchange factor 12 protein, is involved in the modulation of signaling that is mediated by both Rho-family GT Pases or G-protein coupled receptors. The gene is involved in a translocation $\mathrm{t}(11 ; 11)(\mathrm{q} 23 ; 23)$ with the MLL gene which is associated with acute leukemia. 